\title{
The Effect of Propanolol on C-Reactive Protein in Patients with Severe Burns at Dr Soetomo Hospital Surabaya
}

Muhammad Aulia U.H. Iswinarno Doso Saputro Magda Rosalina Hutagalung
Background: The incidence of burns in Indonesia progressively increases with the increase in its population and industries. From January to September 2000, 158 patients were treated in the burn unit of Dr Soetomo Hospital with a mortality rate reaching $5,8 \%$. Burns have a direct effect in causing both local and systemic changes in the body, not occurring in other injuries. In severe burns, a hypermetabolic state can occur, which increases cardiac workload and causes muscle atrophy and other morbidities. The purpose of this study is to examine the effect of propranolol on the hypermetabolic state in severely burned patients by measuring various clinical \& laboratory parameters.

Methods : This is an experimental study using pre and post test control group design with the objective of assessing the treatment outcome with oral propranolol given in 15 consecutive days for burn patients involving 25\%$60 \%$ TBSA. Measurements were taken three times, on day 0,7 and 14 .

Results : Obtained 16 samples divided into 2 groups. In the treatment group, there was a significant decrease in CRP levels on days 0,7 and $14(p<0.05)$. The Mid Arm Circumference variable did not obtain a significant decreasing on days 0,7 and 14 . The albumin level studied showed a significant decreasing on day $0 \& 7$ days with a value of $p=0.045$. From the comparison between the two groups, there were significant differences in CRP levels on days 0 \& 14 , with the mean value of the treatment group $-5.12+2.88$ and the mean value of the control group $2.86+7.37$, and the value of $p=0.019$.

Conclusions: This study successfully proved that the administration of propranolol can overcome the effects of hypermetabolism which is characterized by decreasing in CRP levels.

Keyword: Palatal fracture, Maxillofacial fracture, Facial injuries, Maxillofacial injuries
A burn is a type of injury to tissue caused by contact with a heat source, which may cause high morbidity and mortality requiring special containment procedures from the beginning 1 . In Indonesia, with the increase of population and industry, the number of burns is rising2. In January 2000-September 2000 there were 158 patients treated in the burn unit at $\mathrm{Dr}$ Soetomo General Hospital with a mortality rate of $5.8 \%{ }^{3}$.

In severe burns, hypermetabolism occurs due to cytokine stimulation that increases the stress response due to the inflammatory process. Increased inflammatory mediators IL-8, IL-6, monocyte chemoattractant protein1 and TNF will increase the catabolism and hypermetabolism through hyperinflamation resulting in increased protein catabolism and stress hormones ${ }^{4}$. Stress hormones will increase the production of C-reactive protein (CRP) by hepatocytes ${ }^{5}$.

Arbabi $^{6}$ proved the efficacy of treating hypermetabolism using propranolol in septic patients with satisfactory results, with reduced hypercatabolism, characterized by decreased CRP, suppression of the increased natural cells and mobilization of

Disclosure: The authors herely declare they have no financial interest in the information discussed in this article

lymphocytes ${ }^{7}$ 


\section{Material \& Methods}

The study design is in the form of experimental research using Pre and Post Test Control Group Design with the purpose of evaluating the effect of oral propranolol in burn patients with $25 \%-60 \%$ TBSA.

\section{Inclusion criteria}

- Age = 16-65 years

- Burn TBSA = 20-60\%

- Admission within 72 hours of burn

\section{Exclusion criteria}

- Electric burns

- Pregnant females

- Diabetic, asthma patients

- Known case of hypertension on beta blocker therapy previously

\section{Cases were divided into two groups}

1. Experimental group

2. Control group

Each group consists of 8 patients. The experimental group is given propranolol in a dose of $0.5-1.5 \mathrm{mg} / \mathrm{kg}$ body weight (achieving a reduction in the heart rate by $20 \%$ ) per day (6-8 hourly) orally for 15 days and followedup for 14 days. CRP is measured on day 0,7 and 14.

All patients are subjected to routine investigations prior to starting propranolol therapy. These investigations included blood pressure, heart rate, temperature, complete blood count, serum electrolytes, blood glucose, chest X-ray, and electrocardiography. The therapeutic outcome is assessed based on various clinical and laboratory parameters. The study will be stopped in patients who show features of hypersensitivity, cardiac changes or increased morbidity.

\section{Results}

Data were collected on the day 0, 7 and 14 th, then analyzed using chi-square, Kolmogorov-Smirnov and independent t-test to analyze the variables studied. The results are significant if the $\mathrm{p}$ value is $<0.05$.
Data obtained 16 samples divided into 2 groups, each group consist to 8 patients. The distribution of burn injuries in the treatment group was $20 \%-30 \%$ TBSA 2 people, $30 \%$ $40 \%$ TBSA 3 people, $40 \%-50 \%$ TBSA 1 person, $50 \%-60 \%$ TBSA 2 people, while in the control group $20 \%-30 \%$ TBSA 5 people, $50 \%-60 \%$ TBSA 3 people.

Table 1 Distribution data based on age and sex

\begin{tabular}{lccc}
\hline Variable & $\begin{array}{c}\text { Experimental } \\
\text { group } \\
\mathrm{N}=8\end{array}$ & $\begin{array}{c}\text { Control } \\
\text { group } \\
\mathrm{N}=8\end{array}$ & P value \\
\hline Age & $39,5(28-47)$ & $34,1(20-52)$ & 0,266 \\
Sex & & & 1,000 \\
Male & $7(87,5 \%)$ & $7(87,5 \%)$ & \\
Female & $1(12,5 \%)$ & $1(12,5 \%)$ & \\
\hline
\end{tabular}

Table 2 Variable

\begin{tabular}{lccc}
\hline Variable & $\begin{array}{c}\text { Experimental } \\
\text { group }\end{array}$ & Control group & $\begin{array}{c}\mathrm{P} \\
\text { value }\end{array}$ \\
\hline $\begin{array}{l}\text { Time to } \\
\begin{array}{l}\text { Diagnostic } \\
\text { (hours) }\end{array}\end{array}$ & $11,5 \pm 5,92$ & $8 \pm 6,2$ & 0,102 \\
& & & \\
$\begin{array}{l}\text { Burn Injury } \\
\text { (\% TBSA) }\end{array}$ & $39,31 \pm 12,74$ & $36,43 \pm 18,69$ & 0,431 \\
& & & \\
Mid Arm & $32,31 \pm 3,23$ & $30,25 \pm 10,32$ & 0,6 \\
$\begin{array}{l}\text { Circumference } \\
\text { (cm) }\end{array}$ & & & \\
& $3,02 \pm 0,39$ & $3,06 \pm 0,39$ & 0,832 \\
Albumin (g/dl) & & & \\
CRP (mg/L) & $21,40 \pm 4,79$ & $8,88 \pm 9,12$ & 0,004 \\
\hline
\end{tabular}

Distribution data according to age and sex in each group as listed in table 1 . Based on the results of the statistical analysis, shows that there were no sex differences between the treatment and control groups, with the value of $p=1,000 .(p<0.05)$

In the control group, the CRP did not show a significant difference between days 0 , 7 and 14. While the Mid Arm Circumference variable was statistically significant on day 0 , 7 and 14. ( $\mathrm{p}<0.05$ ). The albumin levels studied were statistically significant on day 0 , 7 and 14. 
In the treatment group, there was a significant decrease in CRP levels on day 0,7 and 14 ( $\mathrm{p}<0.05)$. The Mid Arm Circumference variable did not obtain a statistically significant decreasing on day 0,7 and 14 . The albumin level studied showed a significant decreasing on day $0 \& 7$ days with a value of $p$ $=0.045$.

Table 3 Control Group

\begin{tabular}{|c|c|c|c|c|c|c|}
\hline & \multicolumn{3}{|c|}{ Day- } & \multicolumn{3}{|c|}{$P$ value } \\
\hline & 0 & 7 & 14 & $\begin{array}{c}0 \& \\
7 \\
\end{array}$ & $\begin{array}{c}7 \\
\& 14 \\
\end{array}$ & $\begin{array}{c}0 \& \\
14 \\
\end{array}$ \\
\hline $\begin{array}{l}\text { CRP } \\
(\mathrm{mg} / \mathrm{L})\end{array}$ & $\begin{array}{c}8,88 \pm \\
9,12\end{array}$ & $\begin{array}{c}12,11 \pm \\
8,16\end{array}$ & $\begin{array}{c}11,75 \pm \\
7,24\end{array}$ & $\begin{array}{c}0,36 \\
3\end{array}$ & $\begin{array}{c}0,69 \\
7\end{array}$ & 0,307 \\
\hline $\begin{array}{l}\text { Mid } \\
\text { Arm } \\
\text { Circum } \\
\text { ference } \\
(\mathrm{cm})\end{array}$ & $\begin{array}{c}30,25 \pm \\
10,32\end{array}$ & $\begin{array}{c}28,75 \pm \\
9,80\end{array}$ & $\begin{array}{c}27,90 \pm \\
9,85\end{array}$ & $\begin{array}{c}0,00 \\
3\end{array}$ & $\begin{array}{c}0,04 \\
2\end{array}$ & 0,001 \\
\hline $\begin{array}{l}\text { Albumi } \\
\mathrm{n}(\mathrm{g} / \mathrm{dl})\end{array}$ & $\begin{array}{c}3,06 \pm \\
0,39\end{array}$ & $\begin{array}{c}2,97 \pm \\
0,26\end{array}$ & $\begin{array}{c}2,87 \pm \\
0,59\end{array}$ & $\begin{array}{c}0,32 \\
6\end{array}$ & $\begin{array}{c}0,51 \\
3\end{array}$ & 0,060 \\
\hline
\end{tabular}

Table 4 Experimental Group

\begin{tabular}{lcccccc}
\hline & \multicolumn{3}{c}{ Day- } & \multicolumn{3}{c}{ P value } \\
& 0 & 7 & 14 & 0 \& 7 & $7 \& 14$ & 0 \& \\
& & & & & & 14 \\
\hline CRP & $21,40 \pm$ & $19,04 \pm$ & $16,30 \pm$ & 0,004 & 0,007 & 0,00 \\
$(\mathbf{m g} / \mathbf{L})$ & 4,79 & 5,08 & 4,49 & & & 2 \\
Mid Arm & $32,31 \pm$ & $32,31 \pm$ & $32,12 \pm$ & 0,197 & 0,197 & 0,19 \\
Circumfer & 3,23 & 3,24 & 3,37 & & & 7 \\
ence (cm) & & & & & & \\
& & & & & & \\
Albumin & $3,02 \pm$ & $2,73 \pm$ & $2,71 \pm$ & 0,045 & 0,749 & 0,09 \\
(g/dl) & 0,39 & 0,27 & 0,36 & & & 9 \\
\hline
\end{tabular}

Table 5 Variable Differences

\begin{tabular}{|c|c|c|c|}
\hline & $\begin{array}{l}\text { Experimental } \\
\text { group }\end{array}$ & Control group & $\mathrm{P}$ value \\
\hline \multicolumn{4}{|l|}{ CRP (mg/L) } \\
\hline $0 \& 7$ & $-2,35 \pm 1,60$ & $3,24 \pm 9,40$ & 0,139 \\
\hline $7 \& 14$ & $-2,77 \pm 2,08$ & $-0,37 \pm 2,56$ & 0,058 \\
\hline $0 \& 14$ & $-5,12 \pm 2,88$ & $2,86 \pm 7,37$ & 0,019 \\
\hline \multicolumn{4}{|c|}{$\begin{array}{l}\text { Circumference } \\
(\mathrm{cm})\end{array}$} \\
\hline $0 \& 7$ & $0,00 \pm 0,00$ & $-1,50 \pm 0,93$ & 0,003 \\
\hline $7 \& 14$ & $-0,19 \pm 0,37$ & $-0,85 \pm 0,97$ & 0,092 \\
\hline $0 \& 14$ & $-0,19 \pm 0,37$ & $-2,35 \pm 1,18$ & 0,001 \\
\hline \multicolumn{4}{|c|}{ Albumin (g/dl) } \\
\hline $0 \& 7$ & $-0,29 \pm 0,33$ & $-0,09 \pm 0,25$ & 0,215 \\
\hline $7 \& 14$ & $-0,03 \pm 0,21$ & $-0,10 \pm 0,43$ & 0,553 \\
\hline $0 \& 14$ & $-0,31 \pm 0,47$ & $-0,19 \pm 0,25$ & 0,650 \\
\hline
\end{tabular}

In this study, the treatment and control groups were statistically calculated and compared in CRP, Mid Arm Circumference and albumin data on day 0,7 and 14. From the results of statistical tests, there were significant differences in CRP levels on days 0 $\& 14$, with the mean values of the treatment group $-5.12 \pm 2.88$ and the mean value of the control group $2.86 \pm 7.37$, and the value of $p=$ 0.019. The Mid Arm Circumference variable was declared significant on days $0 \& 7$, with the average value of the treatment group 0.00 \pm 0.00 and the mean value of the control group $-1.50 \pm 0.93$, and the value of $p=0.003$, and days 0 \& 14, with the average value of the treatment group $-0,19 \pm 0.37$ and the mean value of the control group is $-2.35 \pm 1.18$, and the value of $p=0.001$. While for albumin values, overall in both groups showed statistical insignificance. (Table 5)

\section{Discussion}

In severe burns, hyperinflammation occurs due to an increase in inflammatory mediators such as IL-8, IL-6, monocyte chemoattractant protein-1 and TNF so as to increase stress hormones that trigger catabolism and cause hypermetabolism. Hypermetabolism is triggered by an increase in stress hormones that will increase CRP production. Hypermetabolism is characterized by insulin resistance, decreased body weight and muscle mass, increase in heart rate and increase in body temperature.

Hypermetabolism is prevented by pharmacological therapy using propranolol. In the Arbabi (2004) study, propranolol has been shown to reduce hyperkatabolism in sepsis, characterized by decreased CRP, suppressing natural cell increases and mobilization of lymphocytes. Hart, et al. (2002) stated that propranolol is a strong anabolic in the early phase of the hyperkatabolic phase in burns, propranolol will prevent increased lipolysis by inhibiting activation of beta adrenergic receptors so as to reduce fatty infiltration in the liver, increase LBM (Lean Body Mass) and reduce skeletal muscle wasting. Wilson, et al. (2012) 
suggested that further changes to skeletal muscle wasting would be reduced by propranolol by increasing protein synthesis. Increased peripheral lipolysis is inhibited by activation of the beta-2-adrenergic receptor by reducing the plasma concentration of glycerol.

In this study, the difference in initial CRP scores in each group was not similar due to differences in CRP sampling time in the control group with an average of 8 hours and the treatment group with an average of 11.5 hours. Povoa (2004) states that normal CRP levels in blood plasma range from $0.8 \mathrm{mg} / \mathrm{l}$ $10 \mathrm{mg} / \mathrm{l}$. Damayanti (2011) explained that CRP levels will increase and can be detected 6-18 hours after an inflammatory response and will reach a maximum within 48-72 hours, with half-life of 5-7 hours. Propanolol reduces CRP by inhibiting Beta- 1 and Beta- 2 receptors, working to blockade the effects of catecholamines. Catecholamine is the main mediator of the hypermetabolic response. Hypermetabolism and stress hormones will increase the production of $\mathrm{C}$-reactive protein (CRP) from hepatocytes.

Mid Arm Circumference reduction is caused by the dismantling of amino acids from the muscles and the liver as compensation for increased albumin synthesis. Proteins are synthesized from amino acids and regulated by intracellular. The metabolic response to trauma, inflammation, or infection is characterized by a decrease in albumin levels. Changes in the source of amino acids for protein synthesis of albumin from muscle to liver characterized by an increase in phenylalanine and leucine in severe burns will increase protein breakdown throughout the body. Wenjun, et al (2010) obtained from the results of the breakdown of amino acids from whole body proteins accelerated by tissue damage characterized by a decrease in Mid Arm Circumference, and in this study also found a decrease in albumin value in both groups.

Albumin levels in this study group were examined twice a week. The albumin correction is carried out when albumin levels were not in the range of 2.5-3.0 g / dl. In the treatment group albumin levels were maintained by propranolol, characterized by a frequency of correction of blood albumin levels which was less frequently performed than the control group. This is in accordance with research by Nunez (2014) which states that propranolol has the effect of increasing the recycling of intracellular free amino acids, thereby increasing the efficiency of protein synthesis in muscles to maintain albumin levels. Decreased albumin levels in the blood not only because of decreased albumin synthesis due to metabolic and stress response conditions but also exudates that come out of the wound and influence the redistribution of intra and extracellular fluids. Iona (2013) found that there were negative relations between the extent of burns and serum albumin. The wider the burn will further reduce serum albumin levels which can be estimated and calculated mathematically, but the study also states the decrease in serum albumin levels influenced by multifactors is not only based on the extent of burns.

\section{Conclusion}

In this study, the more extensive burns that the more hypermetabolic burns will be higher with a marked increasing in CRP levels. The control group has not reached the CRP peak, but with an upward trend. Propranolol in the treatment group for 14 days were able to reduce CRP levels statistically and clinically. Mid Arm Circumference significantly decreased in the control group. In the treatment group, albumin levels were maintained by propranolol while the control group received a more frequent frequency of albumin correction.

This study successfully proved that the administration of propranolol can overcome the effects of hypermetabolism which is characterized by decreasing in CRP levels 


\section{Reference}

1. 1. Moenajad Y. Luka Bakar: Klinis Praktis. Edisi Kedua. Jakarta: Balai Penerbit FK Universitas Indonesia; 2003.

2. Sjamsuhidajat $\mathrm{R}$, de Jong W.Buku Ajar Ilmu Bedah. Edisi 2. Jakarta: Penerbit Buku Kedokteran EGC; 2005.

3. Iswinarno, Luka Bakar. Surabaya: AUP; 2011.

4. Jeschke MG, Mlcak RP, Finnerty CC, Norbury WB. Burn size determines the inflammatory and hypermetabolic response. Crit Care J. 2007

5. Póvoa Pedro.C-reactive protein: a valuable marker of sepsis. Berlin: Springer-Verlag; 2004

6. Arbabi S, Karla S, Ahrns RN, Wahl WL, Hemmila MR, Wang SC, Brandt MM and Taheri PA. The Journal of Trauma Injury, Infection, and Critical Care. 2004(56).

7. Pemberton $P$, Veenith $T$, Snelson $C$ and Whitehouse T. Is It Time to Beta Block the Septic Patient?. Birmingham: Department of Anaesthesia and Critical Care Medicine. University Hospitals Birmingham NHS Foundation Trust, Queen Elizabeth Hospital Birmingham; 2005. 